\title{
Air Temperature Analysis of a Residential House Using Soliworks Flow Simulation
}

\author{
Estrella C. Macabutas ${ }^{1,2, *}$, Alejandro F. Tongco ${ }^{1}$ \\ ${ }^{1}$ Engineering Graduate Program, School of Engineering, University of San Carlos, Philippines \\ ${ }^{2}$ College of Engineering and Technology, Western Philippines University, Philippines
}

Received July 6, 2020; Revised August 17, 2020; Accepted September 11, 2020

\section{Cite This Paper in the following Citation Styles}

(a): [1] Estrella C. Macabutas, Alejandro F. Tongco, "Air Temperature Analysis of a Residential House Using Soliworks Flow Simulation," Civil Engineering and Architecture, Vol. 8, No. 5, pp. 792 - 800, 2020. DOI: 10.13189/cea.2020.080506.

(b): Estrella C. Macabutas, Alejandro F. Tongco (2020). Air Temperature Analysis of a Residential House Using Soliworks Flow Simulation. Civil Engineering and Architecture, 8(5), 792 - 800. DOI: 10.13189/cea.2020.080506.

Copyright $\bigcirc 2020$ by authors, all rights reserved. Authors agree that this article remains permanently open access under the terms of the Creative Commons Attribution License 4.0 International License

\begin{abstract}
The model house under study is a typical house with a G.I. roofing but it was retrofitted by adding a green-material (bamboo) into, thereby forming a parallel plate air passage. The air, in passing this channel (airgap), undergoes a natural or free convection process of cooling. Buoyant forces cause this downward flow of cooled air through the airgap. The roofing airgap designed to direct this cooled air to the room to be ventilated. The flow through the airgap is laminar because of the low air velocity caused by the free-convection process of cooling. This study evaluated the performance of a house with roofing that was retrofitted with a type of green-material called bamboo. An evaluation applied to 88 square meters of space through air-temperature analysis. The tool used in this analysis was the FloEFD simulation software. The inputs required in setting up the FloEFD model are initial boundary conditions, ambient pressure and temperature, the estimated space heat load (assumed to be constant), and the roof module. Based on the results obtained, the indoor temperature depends on the boundary conditions or the outside environmental temperature. The indoor air temperature decreased an average of $2^{\circ} \mathrm{C}$ from outdoor temperature with the initial conditions of $31^{\circ} \mathrm{C}$ and room heat flux of $300 \mathrm{Watts} / \mathrm{m}^{2}$ with a resultant air movement inside the room ranging from $0.217 \mathrm{~m} / \mathrm{s}$ to $0.651 \mathrm{~m} / \mathrm{s}$. The insulating property of green-material utilized in the roofing system was instrumental in lowering the airgap exit temperature by an average of $4^{\circ} \mathrm{C}$.
\end{abstract}

Keywords Air Temperature, FloEFD, Residential House, Roof, Simulation

\section{Introduction}

In countries located in the tropics such as the Philippines, ventilation and cooling are necessity to sustain the thermal comfort of occupants. Due to the rise in energy cost, this passive cooling method may prove to help alleviate the situation. The idea of passive cooling (passive heating in cold countries) entails the inclusion of passive design concepts in the pre-construction activities by designers.

Many studies on the passive cooling of buildings carried out using the simulation approach. The simulation method has high levels of accuracy [1]. There are buildings that require better circulation air to maintain low-temperature air with high relative humidity [2]. As stated by the American Society of Heating, Refrigerating, and Air-Conditioning Engineers (ASHRAE), thermal comfort is "a condition of the mind in which satisfaction expressed with the thermal environment" [3]. The psychrometric process that occurs in the airgap is a sensible cooling one, and thus, the relative humidity increased while maintaining the constant moisture content of the air. The psychrometric process that the air went through in the airgap is sensible cooling. The study here centered on the structure with airgap integral to the house. The analyses and corresponding evaluations were carried out considering the effects of the mixing of cooled air from the airgap to the room air initially at a temperature equal to boundary conditions. 
Solidworks flow simulation is the thermal analysis that deals with heat transfer to predict air-temperature changes [4] and evaluate the system for temperature and fluid flow that could help designers and Engineers [5]. Using the numerical approach, the building can be designed to alter the condition of temperature and airflow to some extent [6].

The Philippines is fast becoming a highly urbanized country with many establishments such as restaurants, hotels, shopping malls, amenities, and modern houses. In the fast-growing cities, modern housing-built condominiums, apartments, dormitories, or bungalow-type residential houses. The energy demand for cooling is constantly on the rise due to the fast-increasing rate of occupancy. Typical houses in urban areas have uncomfortable space temperatures [7]. Passive cooling may drastically alter the conceptual designs of houses and buildings, providing in-built features to attain low indoor temperatures. Not only in residential houses but also commercial buildings that depend on mechanical ventilation systems may avail of passive cooling concepts to attain lower indoor air temperatures, employing hybrid systems for reasons of the economy [8]. The continued usage of a stand-alone window-type air-conditioning system can lead to respiratory problems of building occupants as they provide an almost $100 \%$ recirculated air [9]. Contrary to this, passive cooling systems provide almost $100 \%$ fresh outside air.

This study can contribute to the growing needs for the low-temperature, high-quality thermal environment by taking advantage of the natural phenomena around us. In addition to this, the research study entails the use of a locally-sourced green-material, preferably with high insulation value. Simulation and analysis were carried out employing Solidworks flow simulation driven by FloEFD. The results presented in this work can provide a reference to the currently applied thermal comfort analysis, especially to residential houses in the tropics. The input to this study is boundary conditions $\left(26^{\circ} \mathrm{C}, 27^{\circ} \mathrm{C}, 28^{\circ} \mathrm{C}, 29^{\circ} \mathrm{C}\right.$, and $30^{\circ} \mathrm{C}$ ). Relative humidity at the boundary conditions is always assumed here to be constant.

\section{Materials and Methods}

\subsection{Model Description}

The modeled residential house consisting of corrugated G.I. sheet, airgap, insulation, and ceiling board made of green materials (bamboo), as proposed in this study is shown in Figure 1.

Figure 1 describes the corrugated roof (G.I. sheet, 12mm) having a low pitch (or slope) of 2/12 (approximately 9.5 degrees). The peak of the roof joins a vertical wall with an airgap underneath to represent a tilted channel formed between two parallel plates. Warm air circulates through the interior of the house, flows through the $30.48 \mathrm{~cm}$-deep airgap, giving its heat to the roofing and flows downward at extremely low rates. Because of the depth of the airgap, the natural convection is somewhat suppressed, and the heat transfer is assumed to be by conduction alone. The warm air at airgap losses some of its heat to the G.I. sheet. The sky and the ambient air serve as the heat sink for the system while the massive construction of the room's concrete walls stores sensible cooling to reduce space conditioning needs. The insulation and ceiling isolate the air in the airgap from the warm room air.

The boundary conditions used for the simulation are: Boundary (box); 24.36 (m) x 15.72 (m) x 12.16 (m); Environmental pressure: 101,325 (Pa); Heat sources: 300 $\left(\mathrm{W} / \mathrm{m}^{2}\right)$; Initial condition: $31\left({ }^{\circ} \mathrm{C}\right)$; Ambient (outdoor) temperature: $26\left({ }^{\circ} \mathrm{C}\right)-30\left({ }^{\circ} \mathrm{C}\right)$; and Radiative surfaces: roof, outside wall, heat sources.

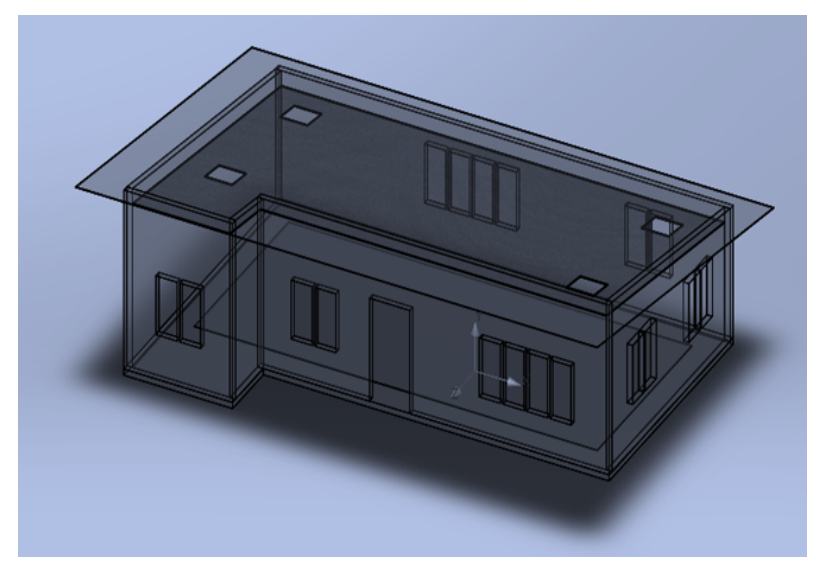

Figure 1. FloEFD model of the residential house

\subsection{Simulation Tool}

In this study, the FloEFD simulation tool used to assess the system's performance in terms of resultant temperatures before and after the mixing of the cooled air and the initially warm room air. Parameters used to simulate the indoor temperature at different nodes. A Solidworks simulation tool driven by FloEFD used to perform simulation works. Solidworks incorporated in the software for the creation of 3D models.

The roof materials, initial boundary conditions of air and surface temperatures, and the heat load are the inputs to the FloEFD model. The model assumed leak-free space conditions for FloEFD analysis. It also assumed that laminar flow of air at the airgap and inside the room. The relative humidity level of $50 \%$, the solar radiation, and heat conduction in solids were intentionally neglected for the purpose of simplicity. The influence of gravity and the increase in the density of cooled air were taken into consideration as the main heat transfer mode in the simulation of convection. The air pressure assumed was one (1) atmosphere $(101,325 \mathrm{kPa})$. The concept of FloEFD simulation is shown in Figure 2. 


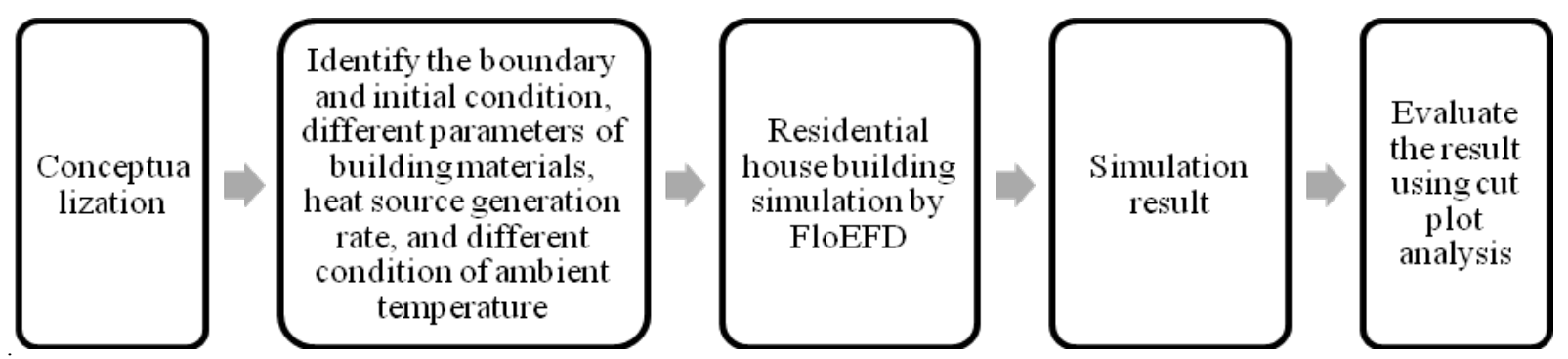

Figure 2. Concept of FloEFD tool for residential house building

\subsection{Analysis of Results}

The operative temperature concept such as GG average fluid temperature (Outside temperature of the house) SG average fluid temperature (outer and inner surface of the roof, an outer surface of the insulation layer, an inner surface of the insulation, an outer surface of ceiling board, and the inner surface of ceiling board), surface average wall temperature, room air temperature, the temperature of the heater, and relative humidity were used to analyze the simulation outcomes. The indices were calculated using an Excel spreadsheet that incorporates the computer program codes for estimation [10].

\section{Results and Discussion}

\subsection{Simulation Tool}

The FloEFD model simulates a typical residential house with a G.I. roof material that was retrofitted by adding a green material's insulation under it to form a parallel plate channel. The air contained in this channel (herein referred to as "airgap") upon being cooled is convected down through the said airgap providing the room or space the needed ventilating airflow. It is then simulated for 300 Watts per square meter only (including the occupants). To retain the thermal comfort inside the room without air-conditioned depends on the environmental temperature and boundary condition.

It was assumed that the environmental pressure was 101, $325 \mathrm{kPa}(1 \mathrm{~atm}$.) and Relative Humidity of 50\%. The initial condition of $31^{\circ} \mathrm{C}$ for the outside wall whereas the environmental temperature and initial solid temperature assigned from $26^{\circ} \mathrm{C}$ to $30^{\circ} \mathrm{C}$. This is the internal analysis type with considered close cavities. The heat transferred focused on conduction, convection, and radiation. The radiative surfaces are the roof, outside wall, and the heat source. The materials used for typical residential houses are GI roofing, green materials for insulation and ceiling board, and concrete materials for the walls.

Figure 3 demonstrates a boundary condition of $26^{\circ} \mathrm{C}$. The resultant air and surface temperature of the inner room was $24.6^{\circ} \mathrm{C}$ and $27.93^{\circ} \mathrm{C}$. The temperature of the air exiting the airgap is $22.2^{\circ} \mathrm{C}$ whereas the inner roof temperature was $22.24^{\circ} \mathrm{C}$. The inner and outer insulation temperatures below the airgap are $21.57^{\circ} \mathrm{C}$ and $21.47^{\circ} \mathrm{C}$ respectively. The inner and outer ceilings attached to the insulation layer are temperatures of $21.57^{\circ} \mathrm{C}$ and $21.69^{\circ} \mathrm{C}$, respectively. The temperature of the surface walls inside the room increased by $7 \%$ on the average from the input boundary condition. Thermal cooling of the room's interior was obtained despite the approximated the room heat load of $300 \mathrm{~W} / \mathrm{m}^{2}$. 


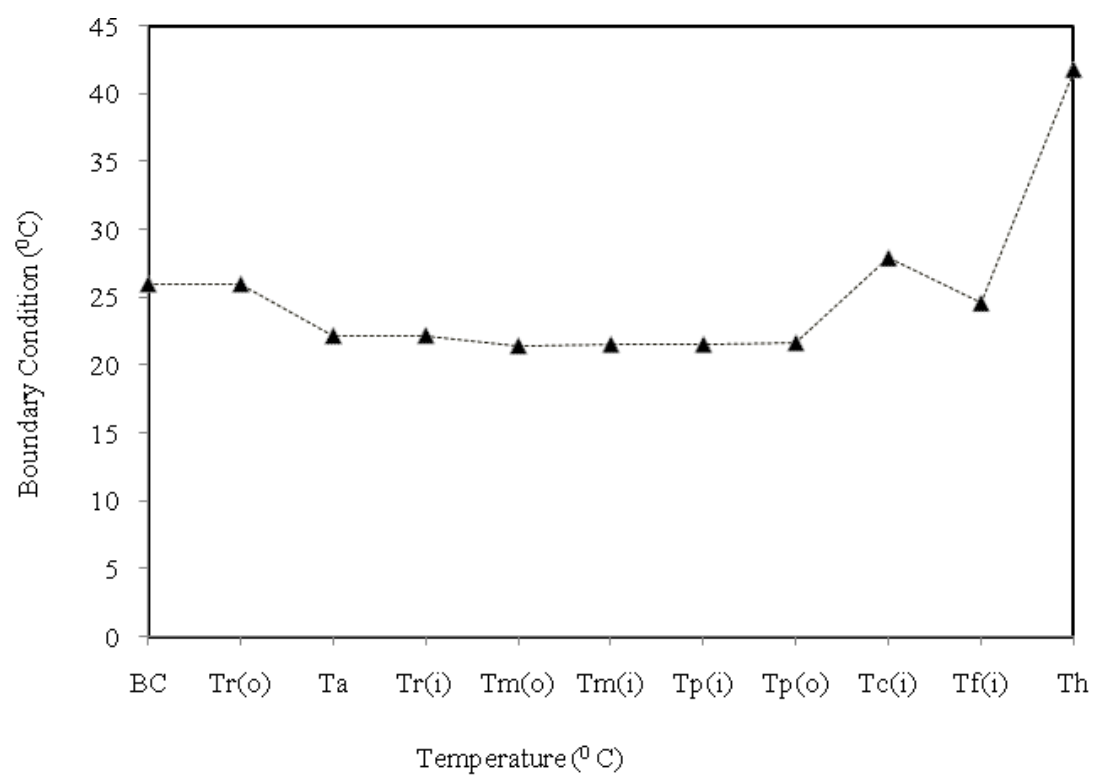

\author{
$\mathrm{BC}$ : Boundary Conditon \\ $\operatorname{Tr}(0)$ : Ambient air temperature \\ (outside) and roof (outer) \\ Ta: Airgap \\ $\operatorname{Tr}(\mathrm{i})$ : Roof temperature (inner) \\ $\operatorname{Tm}(0)$ : Bamboo mat (outer) \\ Tm(i): Bamboo mat (inner) \\ $\mathrm{Tp}$ (i): Bambooply (inner) \\ $\mathrm{Tp}(\mathrm{o})$ : Bambooply (outer) \\ $\mathrm{Tc}(\mathrm{i})$ : Concrete surface wall \\ (indoor) \\ $\mathrm{Tf}(\mathrm{i})$ : Fluid Temperature (indoor) \\ Th: Heater
}

Figure 3. Simulated temperature for the boundary condition of $26^{\circ} \mathrm{C}$

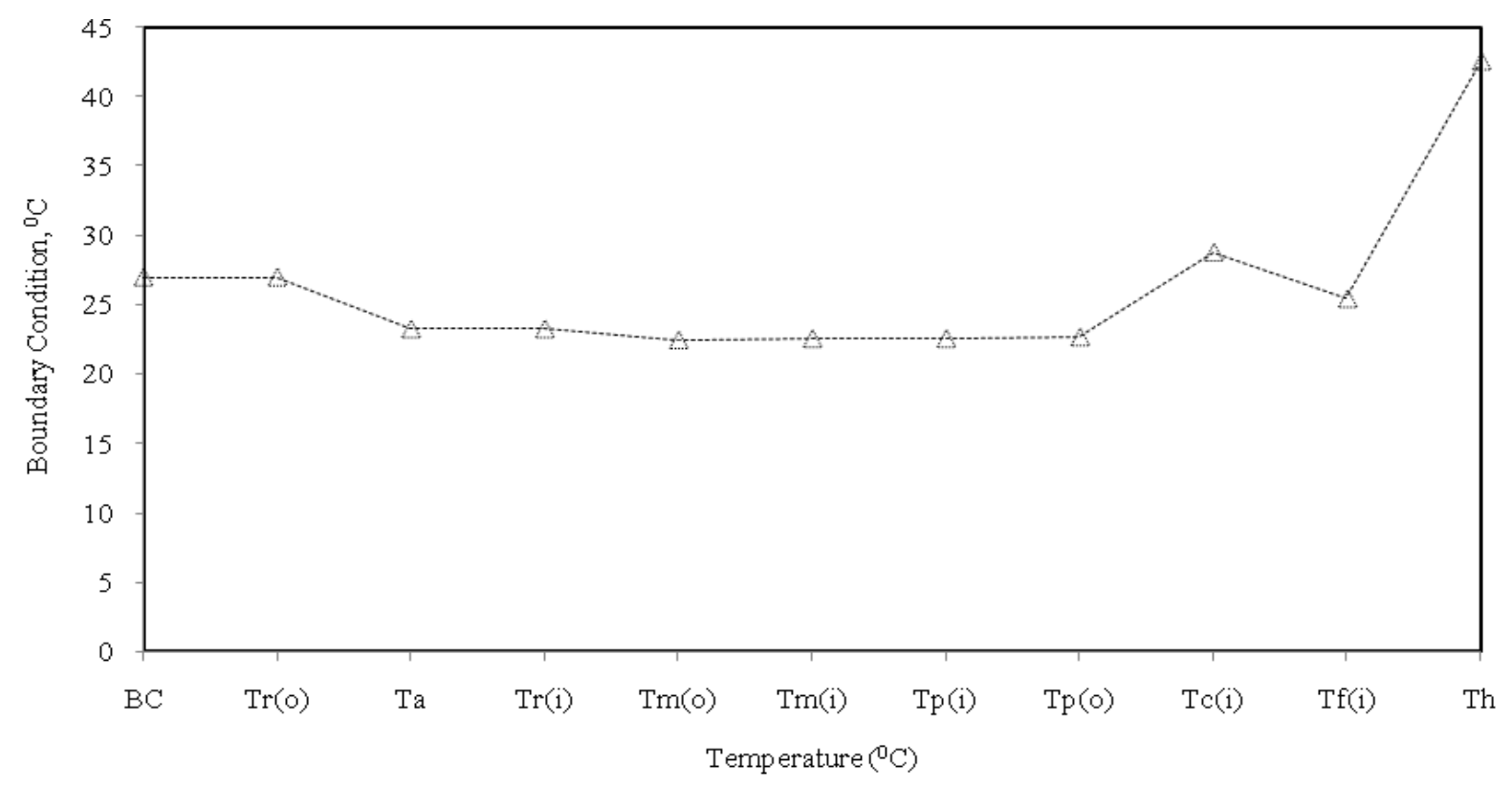

Figure 4. Simulated temperature for the boundary condition of $27^{\circ} \mathrm{C}$

The boundary condition in Figure 4 is $27^{\circ} \mathrm{C}$ with corresponding results of room and wall surface temperature of $25.46^{\circ} \mathrm{C}$ and $28.78^{\circ} \mathrm{C}$, respectively. There are $23.26^{\circ} \mathrm{C}$ and $23.27^{\circ} \mathrm{C}$ for the airgap and the inner roof. While the temperature for the insulation layer of $22.47^{\circ} \mathrm{C}$ (outer) and $22.58^{\circ} \mathrm{C}$ (inner) and the outer ceiling is the same with the inner insulation but the outer insulation $22.69^{\circ} \mathrm{C}$.

Figures 5 to 7 from the boundary condition of $28^{\circ} \mathrm{C}$ to $30^{\circ} \mathrm{C}$. Initially, the inner surface wall temperatures of the room at the input boundary conditions were $29.80^{\circ} \mathrm{C}$, $30.60^{\circ} \mathrm{C}$, and $31.44^{\circ} \mathrm{C}$. For the assumed boundary condition of $28^{\circ} \mathrm{C}, 29^{\circ} \mathrm{C}$, and $30^{\circ} \mathrm{C}$, the resulting air temperatures entering the airgap were $26.49^{\circ} \mathrm{C}, 27.30^{\circ} \mathrm{C}$, and $28.15^{\circ} \mathrm{C}$, respectively. The fluid temperature from the airgap is about $24.19^{\circ} \mathrm{C}, 24.92^{\circ} \mathrm{C}$, and $25.64^{\circ} \mathrm{C}$, and the inner roof is around $24.20^{\circ} \mathrm{C}, 24.93^{\circ} \mathrm{C}$, and $25.65^{\circ} \mathrm{C}$ almost the same with the airgap temperature. The outer temperatures of the insulation are $23.46^{\circ} \mathrm{C}, 24.12^{\circ} \mathrm{C}$, and $24.84^{\circ} \mathrm{C}$ while the inner are $23.56^{\circ} \mathrm{C}, 24.23^{\circ} \mathrm{C}$, and $24.95^{\circ} \mathrm{C}$. Then the inner temperature of the insulation is the same as the inner temperature of the ceiling, however, the outer ceiling temperatures are $23.68^{\circ} \mathrm{C}, 24.35^{\circ} \mathrm{C}$, and $25.07^{\circ} \mathrm{C}$. 


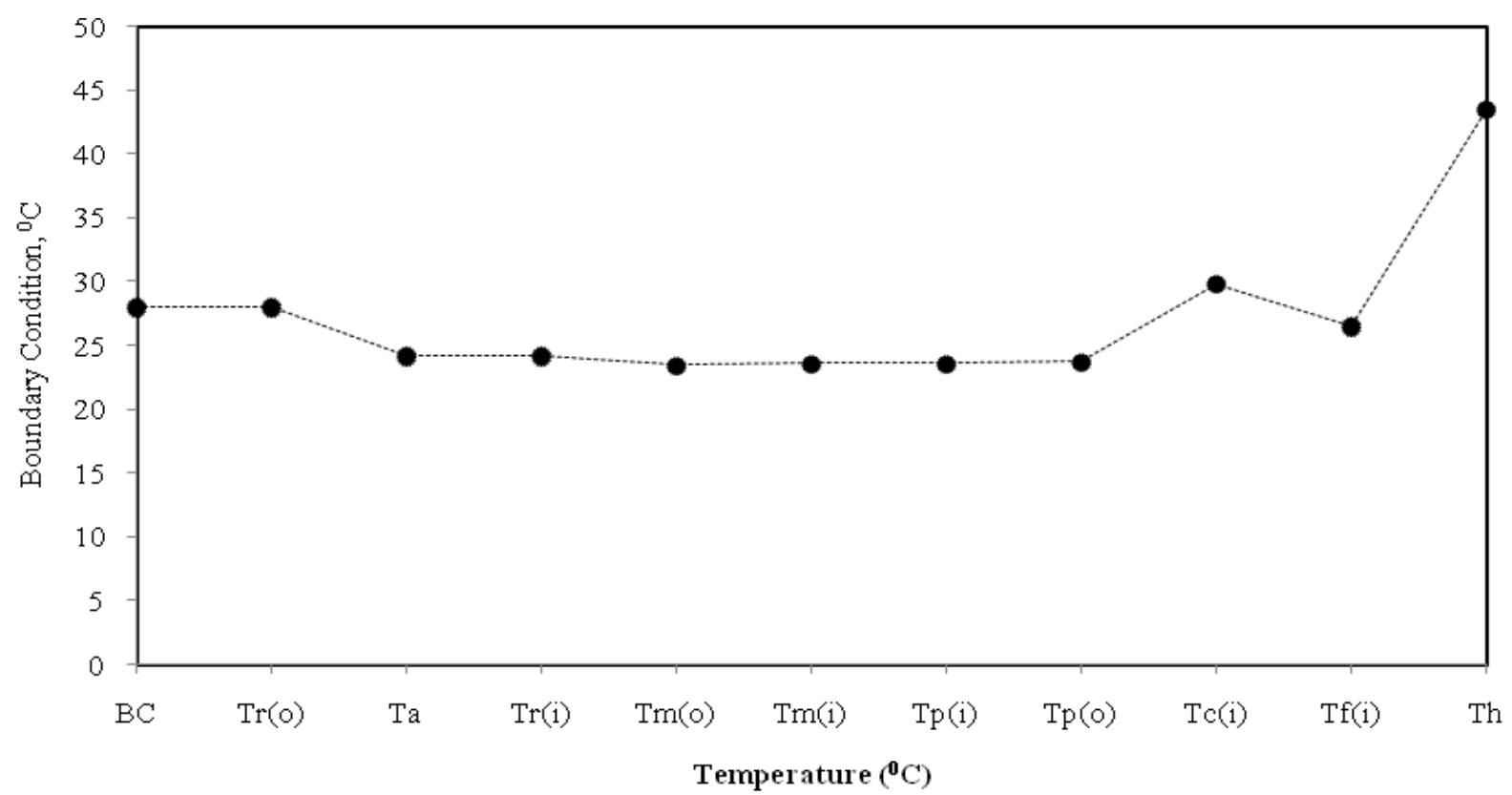

Figure 5. Simulated temperature for the boundary condition of $28^{\circ} \mathrm{C}$

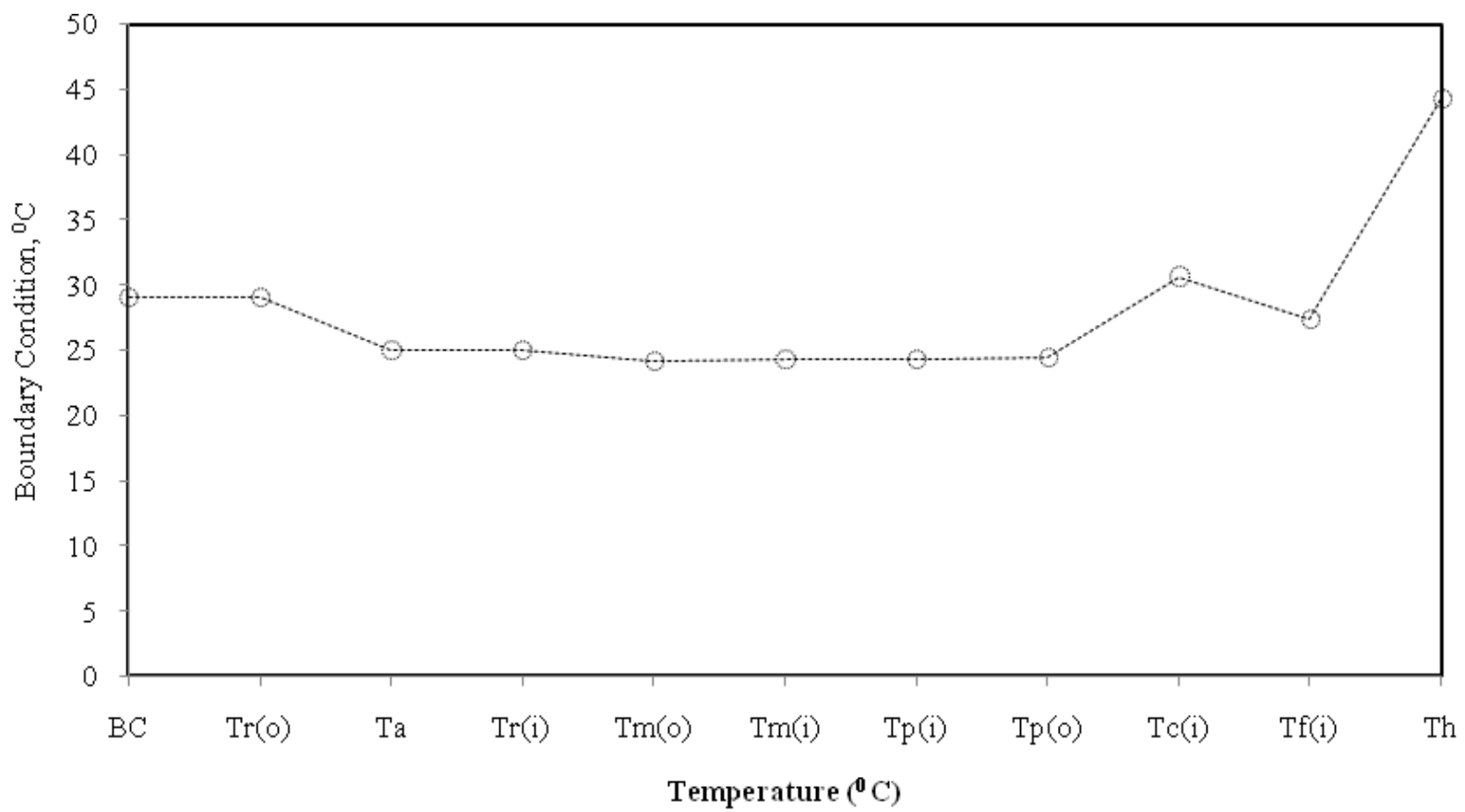

Figure 6. Simulated temperature for the boundary condition of $29^{\circ} \mathrm{C}$

Figure 8 and Table 1 show the result of the simulated boundary condition assigned from $26^{\circ} \mathrm{C}$ to $30^{\circ} \mathrm{C}$. The temperature of the surface wall of the house increases was ranged from $5 \%$ to $7 \%$ to the environmental temperature as shown in Figure 3 to 7 . However, the fluid temperature that flows inside the house decreases from $1.3^{\circ} \mathrm{C}$ to $1.9^{\circ} \mathrm{C}$ from the assigned boundary condition. As you can see, the decreasing temperature of the house depends on the heat inside the room. If the heat lowers than of $300 \mathrm{~W} / \mathrm{m}^{2}$ and the area of 88 square meters of residential house, there are possible the more decreases of the temperature inside the house. The roof module considered aiding for thermal comfort cooling despite the approximated heat inside the room is $300 \mathrm{~W} / \mathrm{m}^{2}$ and the initial condition of $31^{\circ} \mathrm{C}$.

Figure 9 shows the result of simulated air temperature and relative humidity. As you can see in the figure, the relative humidity ranged from $56.25 \%$ to $57.22 \%$. This relative humidity was decreased although the air temperature inside the house decreases from the outside environmental temperature of $26^{\circ} \mathrm{C}$ to $30^{\circ} \mathrm{C}$ with the initial condition of $31^{\circ} \mathrm{C}$. This is the process of mixing of air at constant humidity ratio resulting in a lower temperature but with increased in relative humidity. 


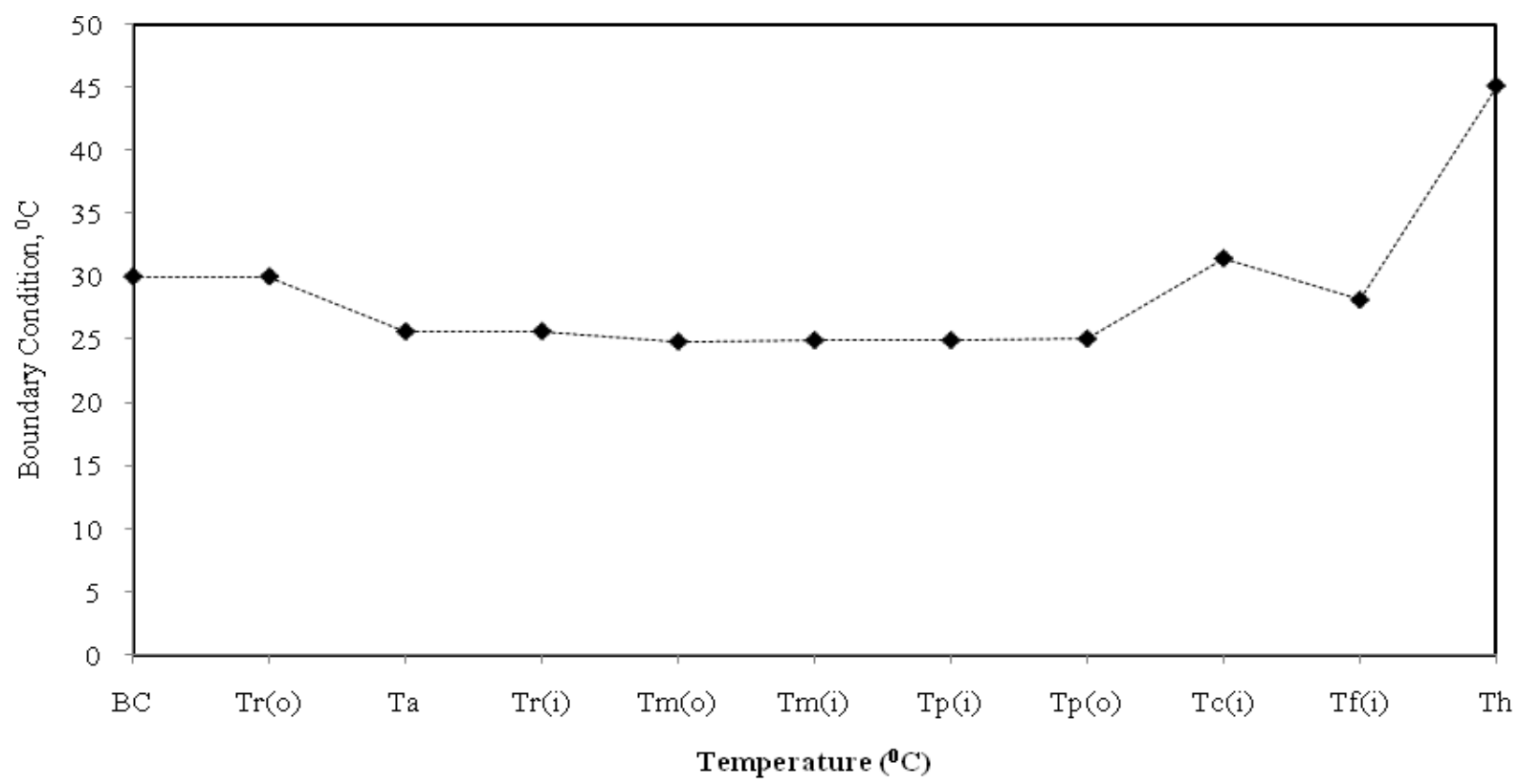

Figure 7. Simulated temperature for the boundary condition of $30^{\circ} \mathrm{C}$
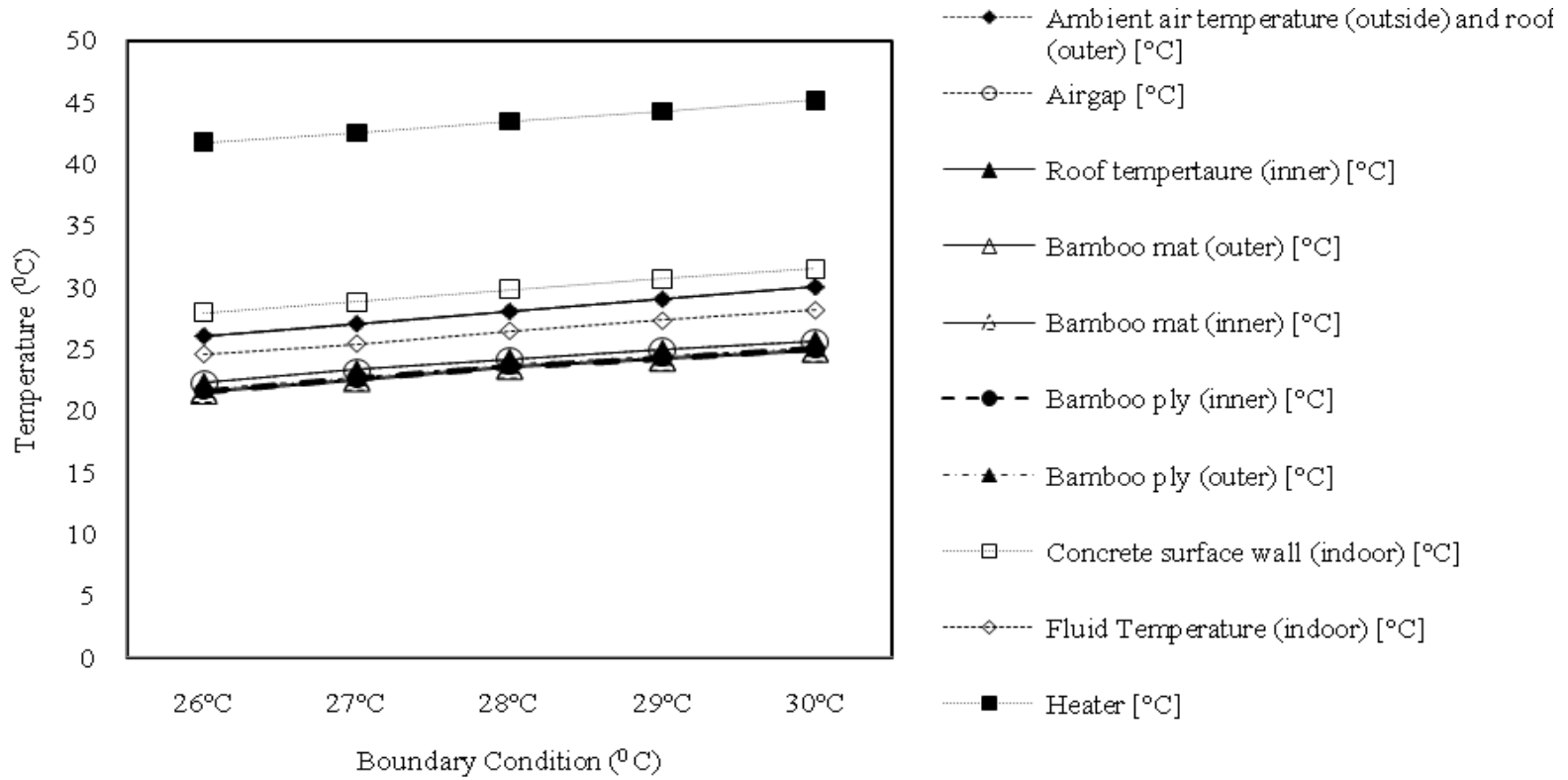

Figure 8. Simulated temperature for the boundary condition from $26^{\circ} \mathrm{C}$ to $30^{\circ} \mathrm{C}$

Table 1. Summary of results of simulated temperature based on the boundary condition from $26^{\circ} \mathrm{C}$ to $30^{\circ} \mathrm{C}$

\begin{tabular}{ccccccccccc}
\hline $\begin{array}{c}\mathbf{B C} \\
\left({ }^{\circ} \mathbf{C}\right)\end{array}$ & $\begin{array}{c}\mathbf{T r}(\mathbf{o}) \\
\left({ }^{\circ} \mathbf{C}\right)\end{array}$ & $\begin{array}{c}\mathbf{T r}(\mathbf{i}) \\
\left({ }^{\circ} \mathbf{C}\right)\end{array}$ & $\begin{array}{c}\mathbf{T a} \\
\left({ }^{\circ} \mathbf{C}\right)\end{array}$ & $\begin{array}{c}\mathbf{T m}(\mathbf{o}) \\
\left({ }^{\circ} \mathbf{C}\right)\end{array}$ & $\begin{array}{c}\mathbf{T m}(\mathbf{i}) \\
\left({ }^{\circ} \mathbf{C}\right)\end{array}$ & $\begin{array}{c}\mathbf{T p}(\mathbf{i}) \\
\left({ }^{\circ} \mathbf{C}\right)\end{array}$ & $\begin{array}{c}\mathbf{T p}(\mathbf{o}) \\
\left({ }^{\circ} \mathbf{C}\right)\end{array}$ & $\begin{array}{c}\mathbf{T c}(\mathbf{i}) \\
\left({ }^{\circ} \mathbf{C}\right)\end{array}$ & $\begin{array}{c}\mathbf{T f}(\mathbf{i}) \\
\left({ }^{\circ} \mathbf{C}\right)\end{array}$ & $\begin{array}{c}\mathbf{T h} \\
\left({ }^{\circ} \mathbf{C}\right)\end{array}$ \\
\hline $\mathbf{2 6}$ & 26.00 & 22.24 & 22.22 & 21.47 & 21.57 & 21.57 & 21.69 & 27.93 & 24.60 & 41.75 \\
$\mathbf{2 7}$ & 27.00 & 23.27 & 23.26 & 22.47 & 22.58 & 22.58 & 22.69 & 28.78 & 25.46 & 42.51 \\
$\mathbf{2 8}$ & 28.00 & 24.20 & 24.19 & 23.46 & 23.57 & 23.57 & 23.68 & 29.80 & 26.49 & 43.43 \\
$\mathbf{2 9}$ & 29.00 & 24.93 & 24.92 & 24.12 & 24.23 & 24.23 & 24.35 & 30.60 & 27.30 & 44.26 \\
$\mathbf{3 0}$ & 30.00 & 25.65 & 25.64 & 24.84 & 24.95 & 24.95 & 25.07 & 31.44 & 28.15 & 45.13 \\
\hline
\end{tabular}




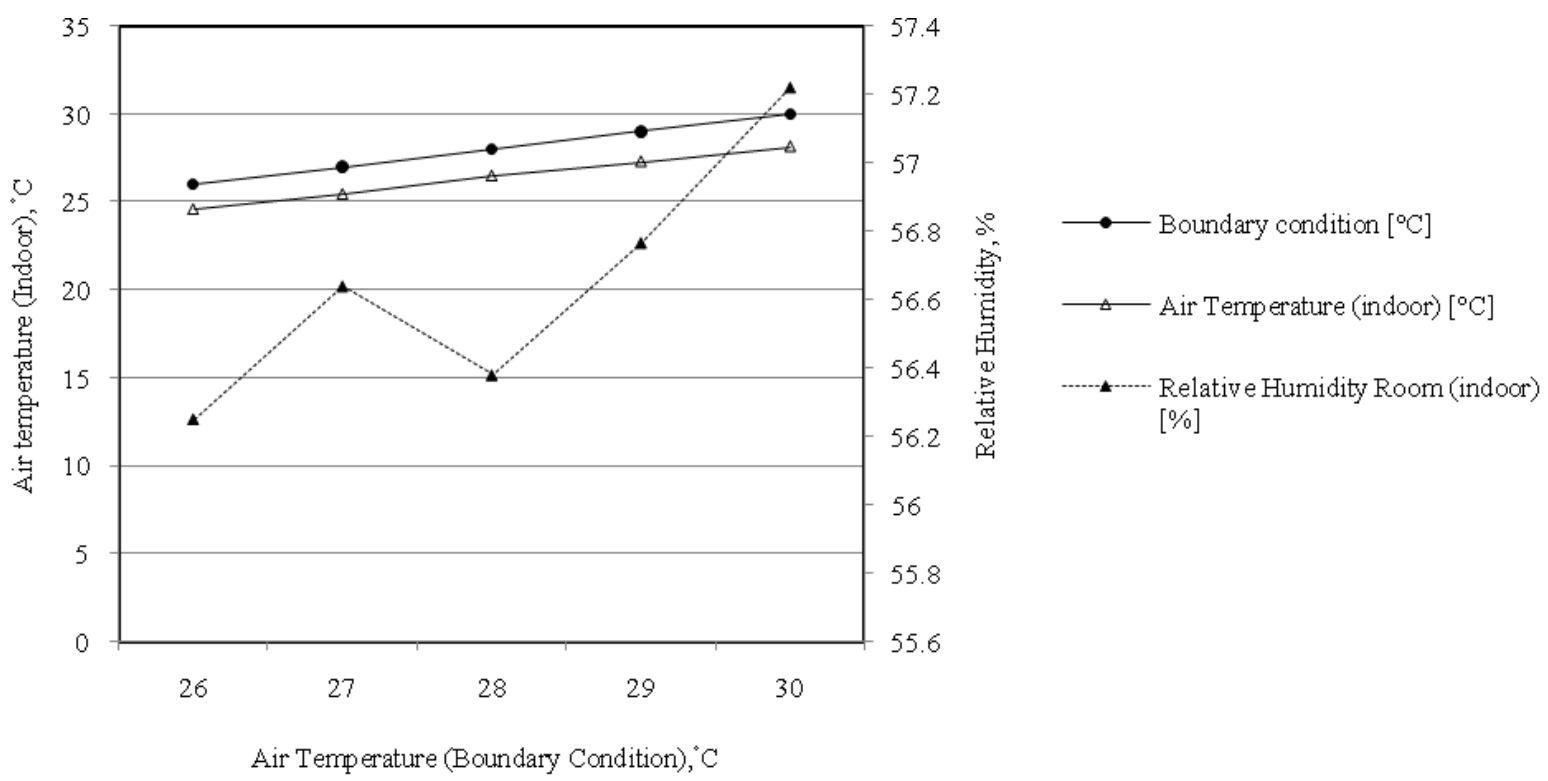

Figure 9. Simulated air temperature and relative humidity for the boundary condition from $26^{\circ} \mathrm{C}$ to $30^{\circ} \mathrm{C}$

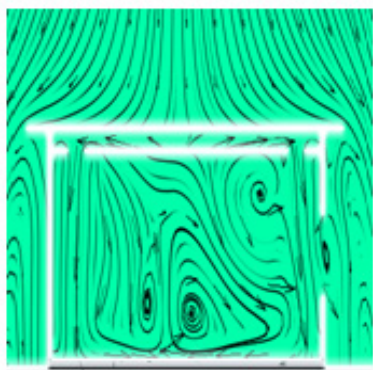

(a)

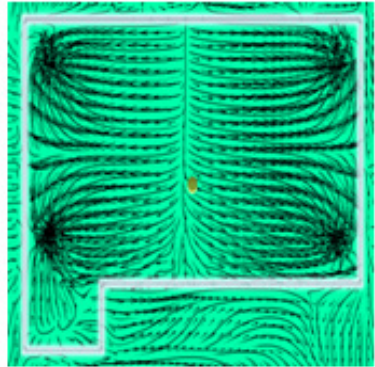

(c)

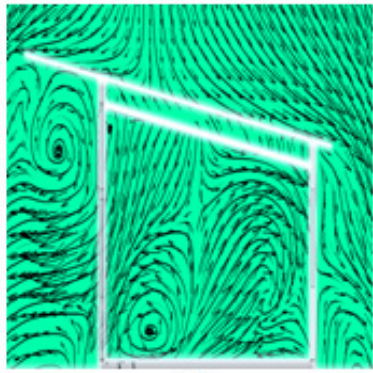

(e)

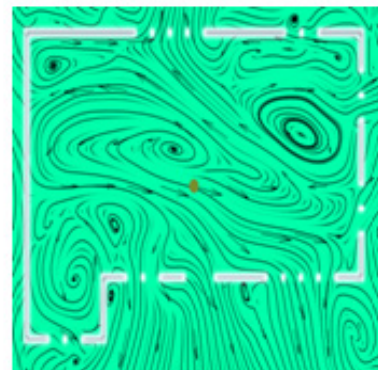

(b)

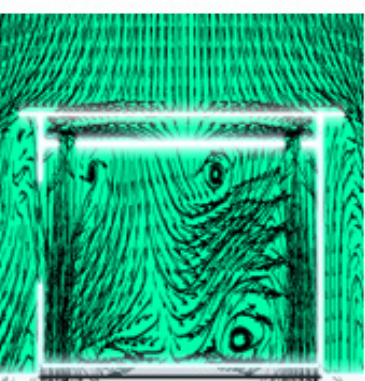

(d)

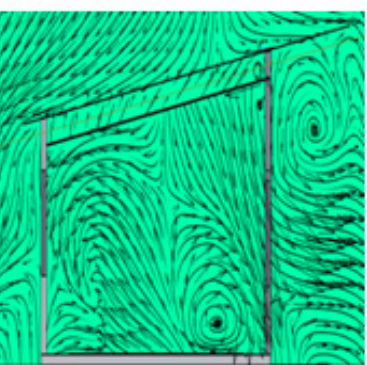

(f)

Figure 10. Air temperature with a boundary condition contours on the xy plane $\left(26^{\circ} \mathrm{C}\right.$ environmental temp) under $300 \mathrm{~W} / \mathrm{m}^{2}$ heat inside the residential house: (a) cut plot 1, (b) cut plot 2, (c) cut plot 3, (d) cut plot 4, (e) cut plot 5, (f) cut plot 6 


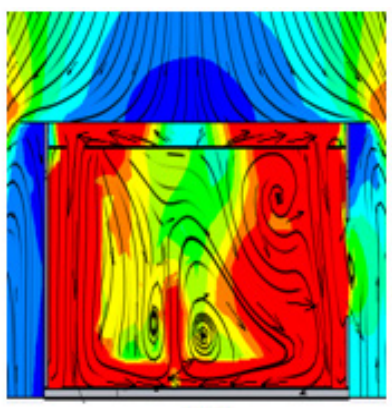

(a)

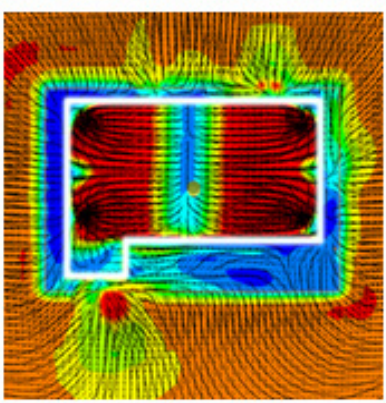

(c)

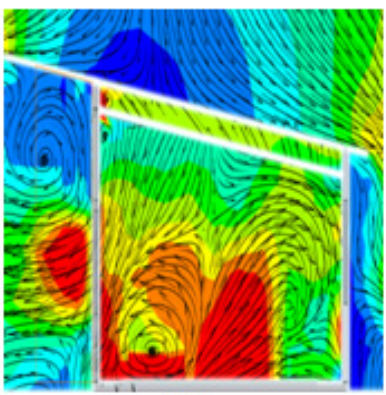

(e)

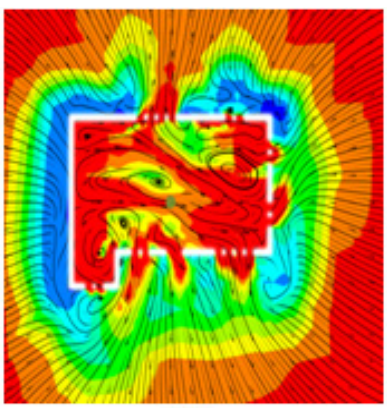

(b)

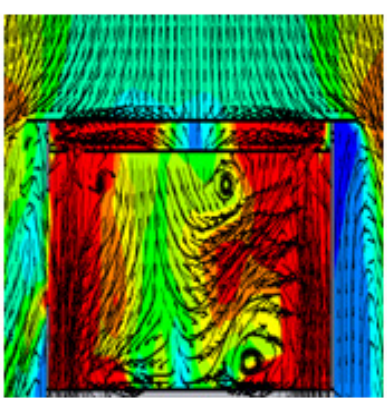

(d)

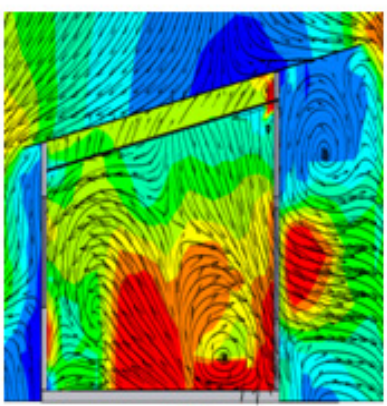

(f)

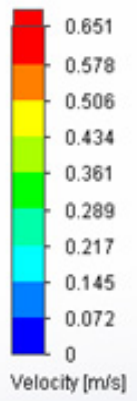

Velocity [mis]

Figure 11. Velocity with a boundary condition contours on the xy plane $\left(26^{\circ} \mathrm{C}\right.$ environmental temp $)$ under $300 \mathrm{~W} / \mathrm{m}^{2}$ heat inside the residential house: (a) cut plot 1, (b) cut plot 2, (c) cut plot 3, (d) cut plot 4, (e) cut plot 5, and (f) cut plot 6

Figure 10 shows the result of a simulated boundary condition at $26^{\circ} \mathrm{C}$ with the initial condition of $31^{\circ} \mathrm{C}$ of different cut plots. In Fig. 10-a and 10-d, are the cut plot shows the front and back view orientation that the air temperature of the holes at the ceiling direct to the airgap. There is a flow of air temperature around $24^{\circ} \mathrm{C}$ to $27^{\circ} \mathrm{C}$. However, the flow is different because of the windows, door, and the flow of the air from the airgap. In Fig. 10-b is the cut plot of 1.5 meters above the ground in the top view orientation. This figure shows the flow of air temperature of less than $27^{\circ} \mathrm{C}$. This cut plot (Fig 10-b) is the temperature that made of the comfort inside the house although the air temperature of the ground higher because of the heat start from the ground then moved upward through the airgap. The cut plot of the airgap as shown in Fig. 10-c for the top view orientation, there is a flow of air temperature around 4 holes in every corner. The air temperature of the airgap is less than $26^{\circ} \mathrm{C}$ because the flow of heat goes up that merge in the air-cooled container (airgap). In Figure 10-e and 10-f are the cut plots of the middle of the house with different orientations. Fig. 10-e is the right view orientation almost the same with the flow of left view (Fig. 10-f) where the air temperature is less than $26^{\circ} \mathrm{C}$.

Figure 11 shows the result of the simulated flow velocity at different orientations at outer surface temperature of $26^{\circ} \mathrm{C}$ and with an ambient condition of $31^{\circ} \mathrm{C}$. This Figure shows the different cut plots to determine the condition of air velocity inside the house. The higher air velocity was found in the two holes at the ceiling in a downward direction and measured between $0.58 \mathrm{~m} / \mathrm{s}$ to $0.65 \mathrm{~m} / \mathrm{s}$ as shown in Fig 11-a and 11-d. Most of the areas were found of a higher air velocity of 1.5 meters above the ground (Fig. 11-b). However, the higher air velocity at the airgap was also found at the 4 holes of the airgap (Fig. 11-c). In the cut plot (e) is the same situation of air velocity of a cut plot (f). Generally, the higher velocity was found in the four corners of the house which may be due to the holes were placed in 
which the flow of circulated air at the airgap.

\section{Conclusions}

The Solidworks software driven by FloEFD simulation was used to analyze the air temperature of a typical residential house with the roof module made of locally sourced green material. To evaluate the air temperature of the residential house the boundary conditions were applied. The simulation results demonstrate the satisfactory uniform velocity and temperature distributions in the occupied region of the house. The results also indicated that analyzing the temperature distributions in the built system with EFD. The thermal EFD simulation model in this study incorporates the latest laminar modeling advancements applicable for room airflow simulation. It resolves the room's air temperature distribution, and predicts air movement. It is found that the simulation outputs can give accurate numerical details of the secondary data such as relative humidity, and air movements.

Referring to the data plot the simulated results as shown for different ambient temperatures around the house would have lower surface temperatures. It was observed that the the airgap at exit has the lowest temperature record. The mean values for the air temperatures at the outside surface of the house were $26^{\circ} \mathrm{C}, 27^{\circ} \mathrm{C}, 28^{\circ} \mathrm{C}, 29^{\circ} \mathrm{C}$, and $30^{\circ} \mathrm{C}$ at $300 \mathrm{~W} / \mathrm{m}^{2}$, average room air temperatures of $24.60^{\circ} \mathrm{C}$, $25.46^{\circ} \mathrm{C}, 26.49^{\circ} \mathrm{C}, 27.30^{\circ} \mathrm{C}$, and $28.15^{\circ} \mathrm{C}$, respectively with an average decrease $2 \mathrm{C}^{\circ}$. The air velocity inside the room ranges from 0.217 to $0.651 \mathrm{~m} / \mathrm{s}$. This indicates that the local green materials were instrumental in the lowering of the supply air temperature by $4 \mathrm{C}^{\circ}$. The materials used in the roof modules were local green material as insulation and ceiling board.

\section{Acknowledgements}

The authors would like to thank to the National Taiwan University of Science and Technology (NTUST), Taipei, Taiwan for granted the research internship program. Furthermore, the authors also acknowledge the Department of Science and Technology - Engineering Research and Development Technology (DOST-ERDT), Philippines for graduate scholarship funding.

\section{REFERENCES}

[1] Q. J. Kwong, N. M. Adam, B. B. Sahari. Thermal comfort assessment and potential for energy efficiency enhancement in modern tropical buildings: A review. Energy and Buildings, 68, 547-557, 2014.

[2] M. T. Ishak, B. Hamzah, Z., Gou, R., Rahim, S. Latif. Thermal Performance of Naturally Ventilated Classroom in the Faculty of Engineering Hasanuddin University, Gowa Campus. International Journal of Engineering and Science Applications, 5(1), 23-36, 2018.

[3] ANSI/ASHRAE, “ANSI/ASHRAE 55: 2004 Thermal Environment Conditions for Human Occupancy," Ashrae, vol. 2004, p 30, 2004.

[4] P. Kurowski. Thermal analysis with Solidworks Simulation 2015 and Flow Simulation 2015. SDC publications, 2015.

[5] A.M. Ali, S. A. Shukor, N.A. Rahim, Z.M. Razlan, Z.A.Z Jamal, K. Kohlhof. Computational Fluid Dynamic (CFD) of Air Conditioning System for Human Thermal Comfort Analysis: A Simulation Study. In 2018 8th IEEE International Conference on Control System, Computing and Engineering (ICCSCE) (pp. 93-98). IEEE, 2018.

[6] S. Driss, Z. Driss, I.K. Kammoun. Computational study and experimental validation of the heat ventilation in a living room with a solar patio system. Energy and Buildings, 119, 28-40, 2016.

[7] B. Li, R. Yao. Urbanization and its impact on building energy consumption and efficiency in China, Renewable Energy 34(9), 1994-1998, 2009.

[8] R. Gifford. The consequences of living in high-rise buildings, Architectural science 25 review 50(1) 2-17, 26, 2007.

[9] A. Aflaki, K. Hirbodi, N. Mahyuddin, M. Yaghoubi, M. Esfandiari. Improving the air change rate in high-rise buildings through a transom ventilation panel: A case study. Building and Environment, 147, 35-49, 2019.

[10] ANSI/ASHRAE Standard 55, Thermal Environment Conditions for Human Occupancy. ASHRAE, 2013. 